\title{
Rhodium-NHC Hybrid Silica Materials as Recyclable Catalysts for [2+2+2] Cycloaddition Reactions of Alkynes
}

\author{
Martí Fernández, ${ }^{[\mathrm{a}]}$ Meritxell Ferré ${ }^{[\mathrm{b}]}$ Anna Pla-Quintana, ${ }^{[\mathrm{a}]}$ Teodor Parella,${ }^{[\mathrm{b}, \mathrm{c}]}$ Roser Pleixats $^{*[\mathrm{~b}]}$ and \\ Anna Roglans*[a]
}

\begin{abstract}
Bis-silylated dihydroimidazolium salt 1 and monosilylated imidazolium salt 2 are transformed to $(\mathrm{NHC}) \mathrm{RhCl}(\mathrm{COD})$ complexes 3 and $\mathbf{4}$, which allow the preparation of hybrid silica materials either by sol-gel or grafting processes. After a full characterization of the materials by means of solid state NMR, $\mathrm{N}_{2}$-sorption measurements, thermogravimetric analysis (TGA) and elemental analysis, the catalytic activity is evaluated in the [2+2+2] cycloaddition of alkynes. Excellent yields of the cycloadducts are obtained for up to six consecutive cycles with the grafted material, using a simple filtration to recover the catalyst. Both conventional and microwave heating prove to be effective for the process described.
\end{abstract}

\section{Introduction}

The transition-metal catalysed [2+2+2] cycloaddition reaction of unsaturated substrates is a very simple and atom-economic strategy to obtain polysubstituted six-membered carbo- and heterocyclic molecules. ${ }^{[1]}$ Many examples of [2+2+2] cycloadditions catalyzed by different transition metals have been described. ${ }^{[1]}$ With regards to the rhodium-catalyzed $[2+2+2]$ cycloaddition of three alkynes to afford highly substituted and/or annulated benzenes, two catalytic systems have proved to be particularly efficient: the Wilkinson complex, which was first used in this reaction by Grigg et al. ${ }^{[2]}$ and which is now used as a neutral rhodium complex, ${ }^{[3]}$ and the combination of a cationic rhodium complex and a BINAP-type ligand, which has been extensively explored by the groups of Tanaka and Shibata ${ }^{[4]}$ and forms a highly active and versatile cationic catalyst.

Given that phosphine ligands are prone to oxidation, resulting in catalyst deactivation and the hampering of the purification of the product, other stabilizing ligands, such as $\mathrm{N}$-heterocyclic carbenes $(\mathrm{NHC})$, are increasingly used as alternatives for

[a] M. Fernández, Dr. A. Pla-Quintana, Prof. A. Roglans Institut de Química Computacional I Catàlisi and Departament de Química

Universitat de Girona

Campus de Montilivi, 17071, Girona, Catalonia, Spain

Fax: (+) 34972418150

E-mail: anna.roglans@udg.edu

[b] M. Ferré, Dr. T. Parella, Prof. R. Pleixats

Departament de Química and Centro de Innovación en Química Avanzada (ORFEO-CINQA)

Universitat Autònoma de Barcelona, Cerdanyola del Vallès, 08193 ,

Barcelona, Catalonia, Spain

E-mail: roser.pleixats@uab.cat

[c] Dr. T. Parella

Servei de RMN

Universitat Autònoma de Barcelona, Cerdanyola del Vallès, 08193 ,

Barcelona, Catalonia, Spain

Supporting information for this article is given via a link at the end of the document. stabilizing transition-metal catalysts. ${ }^{[5]}$ Furthermore, this type of ligands can have a dramatic influence on both reactivity and selectivity. Rh-NHC complexes have only been described by our group as efficient catalysts for intra- and partially intramolecular $[2+2+2]$ cycloaddition reactions of alkynes, ${ }^{[6]}$ although NHCcomplexes of other metals such as ruthenium, cobalt, nickel and iron have been proved to be efficient catalysts in $[2+2+2]$ cycloaddition reactions by other groups. ${ }^{[7]}$

The recovery and reuse of the catalytic system, especially when this is based on transition metals, is an important challenge in organic synthesis both from an economical and environmental point of view. In the field of $[2+2+2]$ cycloaddition reactions, few examples of the recyclability of catalytic systems have been reported. Among them, several strategies have been tested for the recovery of catalysts: i) the anchoring of a metal complex to a polystyrene resin; ${ }^{[8]}$ ii) the use of molten salts as immobilizing agents; ${ }^{[9]}$ iii) the use of a water soluble catalyst; ${ }^{[10]}$ iv) the immobilization of the ligand at the surface of a dendrimer, ${ }^{[11]}$ and v) the recovery of air stable complexes by column chromatography. ${ }^{[12]}$ In this field, the formation of hybrid silica materials is attractive as a means of achieving supported catalysts based on metal complexes. These materials combine the advantages of a silica matrix, such as high surface area, thermal and mechanical stability and chemical inertness, with the properties of the organometallic precursor. ${ }^{[13]}$ Indeed, the sol-gel hydrolytic condensation of organo-alkoxysilanes ${ }^{[14]}$ is a convenient method for the preparation of hybrid silica materials with targeted properties. ${ }^{[15,16]}$ Moreover, the surfactant-assisted sol-gel synthesis or the grafting on a mesostructured silica are commonly employed routes for the synthesis of mesostructured hybrid silicas ${ }^{[17]}$ with high surface areas and large pore sizes.

Silica supported catalysts have also been used in $[2+2+2]$ cycloaddition reactions as a recovery strategy. $\mathrm{Yu}$ et al. ${ }^{[18]}$ immobilized a $\mathrm{Pd}(\mathrm{II})$ complex with a bidentate bis-pyridyl ligand on a range of polysiloxanes with controllable solubility, affording materials which proved to be efficient and recyclable catalysts in the $[2+2+2]$ cyclotrimerization of alkynes. Blümel et al. ${ }^{[19]}$ described the use of carbonylnickel( 0$)$ catalysts with mono- and bidentate phosphine ligands immobilized on hybrid silica materials as recyclable catalysts for the cycloaddition of phenylacetylene. More recently, Hapke et al. ${ }^{[20]}$ described that the air-stable cobalt complex they recovered by column chromatography ${ }^{[12 a]}$ could be grafted on a silica support through a siloxane linker at the $\mathrm{Cp}$-moiety. The heterogeneous Co-catalyst showed moderate activity in the cycloaddition between 1,6heptadiyne and benzonitrile to afford a pyridine derivative. However, the catalytic system deactivates upon recycling. Given our interest in the use of Rh-NHC complexes for the $[2+2+2]$ cycloaddition reaction, we undertook the present project with the idea of immobilizing Rh-NHC complexes on silica materials. In this study imidazolium salts conveniently 
functionalized with trialkoxysilyl groups either in the carbon backbone or in the nitrogen atom will be complexed with Rh and incorporated into hybrid silica materials either by a sol-gel or a grafting process. Some few hybrid silica based Rh-NHC materials have already been synthesized and proved to be efficient catalysts in Rh catalyzed reactions, ${ }^{[21]}$ but to the best of our knowledge they have not been reported as catalysts for the $[2+2+2]$ cycloaddition reaction, which is the aim of the present work.

\section{Results and Discussion}

\section{Synthesis and characterization of Rh-NHC}

In the last few years, we have made some contributions into recyclable catalysts based on hybrid silica materials. We have described a silica-supported Hoveyda-Grubbs' type complex through the NHC ligand by performing a sol-gel co-gelification process of a silylated NHC-Ru monomer with tetraethoxysilane (TEOS). The new material proved to be an efficient recyclable catalyst for ring-closing metathesis reactions. ${ }^{[22]}$ Furthermore, the sol-gel co-condensation of a silylated Pd-NHC complex with TEOS to afford the corresponding hybrid silica material was also described. This supported palladium complex was efficiently used as a recyclable catalyst in the Heck, Suzuki and Sonogashira coupling reactions. ${ }^{[23]}$ Having developed efficient syntheses for both nitrogen and backbone functionalized imidazolium salts, we decided to evaluate their complexation ability with rhodium. Therefore, we first studied the ability of silylated imidazolium salts $\mathbf{1}$ and $\mathbf{2}$ to coordinate rhodium (Scheme 1).

The first attempt to synthesize a Rh-carbene complex from the imidazolium salt $\mathbf{1}$ followed the procedure reported by Dastgir and Green. ${ }^{[24]}$ This method was based on the treatment of the imidazolium salt with $\mathrm{Ag}_{2} \mathrm{O}$ to afford a $\mathrm{NHC}-\mathrm{Ag}(\mathrm{I})$ complex followed by transmetallation with $[\mathrm{Rh}(\mu-\mathrm{Cl})(\mathrm{COD})]_{2}$. However, in our case only decomposition to elemental silver and the recovery of $\mathbf{1}$ were observed.

Recently, Esteruelas and Yus ${ }^{[25]}$ have described an alternative method which used the $[\mathrm{Rh}(\mu-\mathrm{OMe})(\mathrm{COD})]_{2}$ complex in the presence of an imidazolium salt to form the corresponding Rh$\mathrm{NHC}$ species directly. The methoxide anion deprotonates the imidazolium ring and releases methanol from the metal centre. Subsequent coordination of the resulting NHC ligand and the chloride anion to the rhodium atom affords the desired Rhcarbene complex.

In order to avoid side-etherification reactions with the triethoxysilyl groups of our salts $\mathbf{1}$ and $\mathbf{2}$, we used the analogous non-commercially available ethoxy-complex, $[\operatorname{Rh}(\mu-\mathrm{OEt})(\mathrm{COD})]_{2}$, which was prepared from $[\mathrm{Rh}(\mu-\mathrm{Cl})(\mathrm{COD})]_{2}$ by a nucleophilic substitution of the chloride ligands by ethoxide. When bissilylated imidazolium salt 1 was mixed with $[\mathrm{Rh}(\mu-\mathrm{OEt})(\mathrm{COD})]_{2}$ in anhydrous dichloromethane at room temperature for 15 hours, the desired rhodium complex 3 was obtained in a $60 \%$ isolated yield. Applying the same procedure to the imidazolium salt 2 , a $91 \%$ yield of the monosilylated rhodium complex 4 was obtained in 4 hours (Scheme 1).

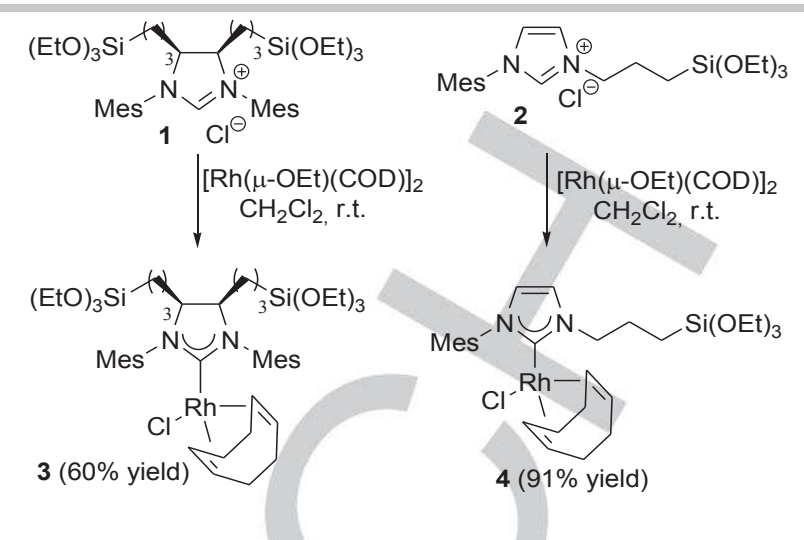

Scheme 1. Synthesis of Rh-NHC complexes 3 and 4. Mes: 2,4,6trimethylphenyl.

Both complexes $\mathbf{3}$ and $\mathbf{4}$ were fully characterized by ESI-HRMS, ${ }^{1} \mathrm{H}$ and ${ }^{13} \mathrm{C}-N M R$. ESI-HRMS spectra of complex 3 showed a peak at $m / z=925.4470$, corresponding to $[\mathrm{M}-\mathrm{Cl}]^{+}$. The same behaviour was observed for complex 4 , which showed a peak at $m / z=601.233$, which also corresponded to the same chloride loss. As a result of hindered rotation around the carbene carbonrhodium bond, two different sets of signals in a $4: 1$ ratio are observed in the ${ }^{1} \mathrm{H}$ and ${ }^{13} \mathrm{C}$ NMR spectra of complex 3 . Six different signals corresponding to the methyl groups in the aromatic ring can be seen in the ${ }^{1} \mathrm{H}-\mathrm{NMR}$ spectrum: the major isomer presented three signals at 2.26, 2.30 and $2.63 \mathrm{ppm}$ whereas the signals corresponding to the minor isomer appeared at $2.29,2.36$, and $2.52 \mathrm{ppm}$. The ${ }^{13} \mathrm{C}-\mathrm{NMR}$ spectrum displays two sets of doublets: at $67.1 \mathrm{ppm}\left(J_{\mathrm{Rh}-\mathrm{C}}=14.5 \mathrm{~Hz}\right.$, major isomer) and $68.3 \mathrm{ppm}\left(\mathrm{J}_{\mathrm{Rh}-\mathrm{C}}=14.0 \mathrm{~Hz}\right.$, minor isomer), corresponding to the methylene carbons of the COD ligand, and at $96.8 \mathrm{ppm}\left(J_{\mathrm{Rh}-\mathrm{C}}=\right.$ $6.9 \mathrm{~Hz}$, major isomer) and $96.5 \mathrm{ppm}\left(J_{\mathrm{Rh}-\mathrm{C}}=7.0 \mathrm{~Hz}\right.$, minor isomer), corresponding to the olefinic carbons of the COD ligand. The carbene carbon atom of the NHC ligand coordinated to Rh appeared as a doublet at $213.2 \mathrm{ppm}$ with a coupling constant of $J_{\text {Rh-C }}=48.0 \mathrm{~Hz}$. High-temperature ${ }^{1} \mathrm{H}$-NMR experiments at up to $95^{\circ} \mathrm{C}$ were carried out in an unsuccessful attempt to observe the interconversion between the two isomers. The formation of two diastereoisomers has previously been described by Köhler et al. ${ }^{[26]}$ in the synthesis of a Rh complex derived from 4,5-diallyl1,3-dimesityl-4,5-dihydroimidazolium chloride, which in our case is a precursor of the synthesis of $\mathbf{1}$ (see Supporting Information). In this study, the authors also found that no dynamic process was observed by variable-temperature ${ }^{1} \mathrm{H}$ NMR experiments up to $70^{\circ} \mathrm{C}$. In an attempt to identify the relative geometry of the two rotamers, NOESY experiments were planned. Since Rh complex 3 containing triethoxysilyl groups is prone to be hydrolyzed under air conditions, the NMR study was performed with the already described Rh-carbene complex derived from the allylic precursor of imidazolium salt $\mathbf{1}$ (named 3 -allyl), which analogously gives a double set of signals with a $4: 1$ isomers ratio. The square planar rhodium complexes feature the carbene ligand in a perpendicular orientation to the square-plane of the complex and cis to the chlorine atom. Both diastereoisomers have a plane of symmetry corresponding to the square-plane of the complex. The NOESY data reveal that the two allyl chains of the major isomer point to the $\mathrm{Cl}$ atom while in the minor isomer they point to the COD ligand (Figure 1). Whereas in the major isomer both the olefin 
COD proton and the $\mathrm{H}$ of the NHC core give a cross-peak with the same ortho methyl of the mesityl, in the minor isomer both protons correlate to a different ortho methyl of the mesityl which is perpendicular to the dihydroimidazole ring. These results can be extrapolated to allow us to conclude that the same type of structures would be found in complex 3 .
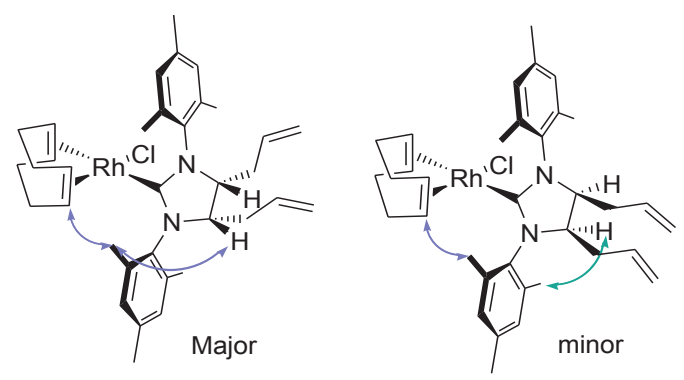

Figure 1. Representation of the two isomers of 3-allyl showing the major NOESY correlations observed.

In the ${ }^{1} \mathrm{H}-\mathrm{NMR}$ spectra of complex 4 , three different methyl and two aromatic signals corresponding to the mesityl ring were observed. The methylene group attached to the second nitrogen atom of the $\mathrm{NHC}$ ligand appeared overlapped with COD ligand signals at around $2 \mathrm{ppm}$. Overlapping was also found at $1.5 \mathrm{ppm}$ between the signals of the central $\mathrm{CH}_{2}$ unit of the silylated chain and protons of the cyclooctadiene ligand. The $\mathrm{CH}_{2}$ group next to the $\mathrm{Si}$ atom appeared at $0.77 \mathrm{ppm}$ as a triplet. In the ${ }^{13} \mathrm{C} \mathrm{NMR}$ spectrum, two doublets at 96.7 and $96.9 \mathrm{ppm}$ corresponded to the olefinic carbons of the $\mathrm{COD}$ ligand (Rh-C coupling constants of $7.3 \mathrm{~Hz}$ and $7.1 \mathrm{~Hz}$, respectively). Two additional doublets at 67.4 and $68.3 \mathrm{ppm}$ were attributed to the methylene carbons of the COD ligand (Rh-C coupling constants of 14.7 and $14.2 \mathrm{~Hz}$ ). The carbene carbon atom of the NHC ligand coordinated to Rh appeared at $181.6 \mathrm{ppm}$ as a doublet with a Rh-C coupling constant of $51.5 \mathrm{~Hz}$.

Synthesis and characterization of organic-inorganic hybrid silica materials M1-M4

Two different materials $\mathbf{M} 1$ and $\mathbf{M} 2$ were prepared from complex 3 by cogelification with different amounts of tetraethoxysilane (molar ratios $3:$ TEOS of $1: 14$ and 1:30, respectively). The reactions were performed under nitrogen atmosphere in anhydrous DMF at room temperature under nucleophilic conditions using a stoichiometric amount of water (with respect to the ethoxy groups) and tetrabutylammonium fluoride as the catalyst ( $1 \mathrm{~mol} \%$ with respect to $\mathrm{Si}$ ). Both solutions gelified after one hour and were aged for six days at room temperature under nitrogen atmosphere. They were then filtered and the solid was washed successively with ethanol, acetone and anhydrous diethyl ether. The resulting powders were dried overnight under vacuum at $40^{\circ} \mathrm{C}$ to afford both materials as an orange powder (Scheme 2).

With complex 4 two different materials were also prepared using two different methodologies. Whereas hybrid silica M3 was prepared by cogelification with tetraethoxysilane (molar ratio 1:30), as previously described for complex $\mathbf{3}$, the material M4 was obtained by grafting to the mesostructured silica SBA-15 under standard conditions (in refluxing anhydrous toluene under nitrogen atmosphere for 24 hours) (Scheme 3).

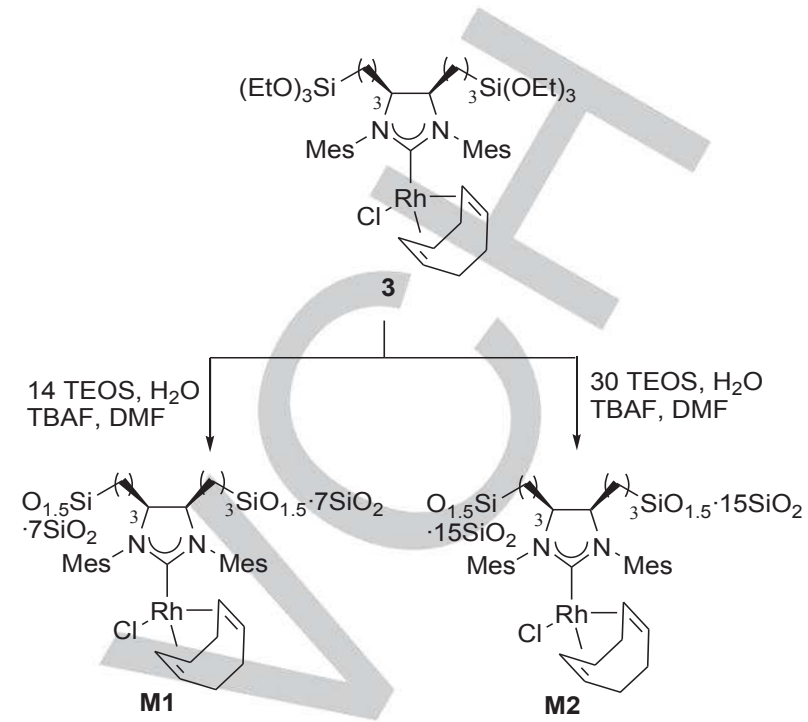

Scheme 2. Synthesis of hybrid silica materials M1 and M2.
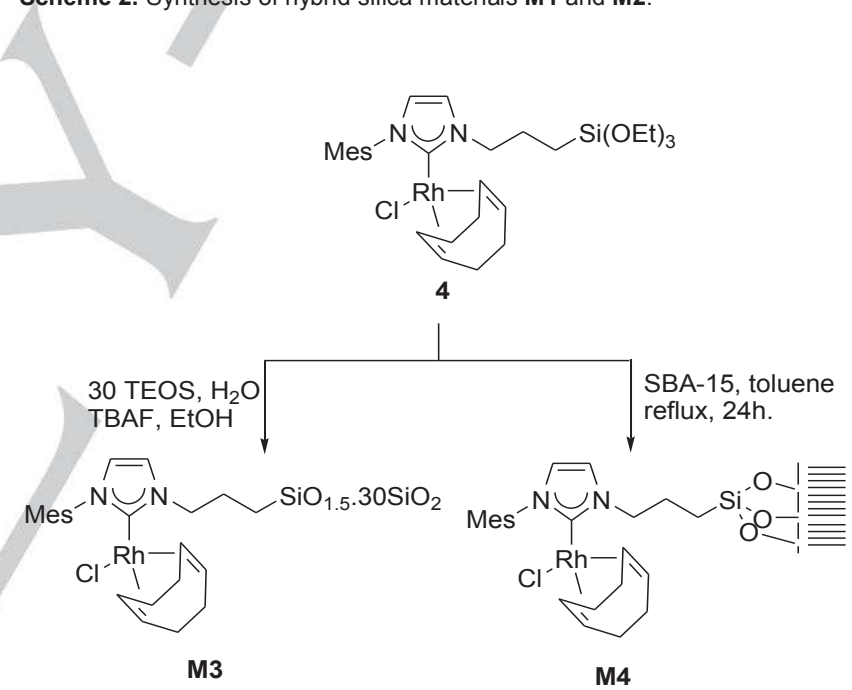

Scheme 3. Synthesis of hybrid silica materials M3 and M4.

The materials were characterized by solid state ${ }^{29} \mathrm{Si}$ NMR and ${ }^{13} \mathrm{C}$ NMR (only for M1), $\mathrm{N}_{2}$-sorption measurements, thermogravimetric analysis (TGA) and elemental analysis, and the amount of rhodium was determined by inductively coupled plasma (ICP). Some analytical and textural data are summarized in Table 1. The TGA curves of all materials (Supporting Information) showed a weight decrease of less than $5 \%$ below $200{ }^{\circ} \mathrm{C}$ attributed to the loss of the physisorbed water and the remaining uncondensed ethoxy groups. A more significant weight loss was then found in the $250-500{ }^{\circ} \mathrm{C}$ range, assigned to the decomposition of the organometallic constituent. We obtained a molar ratio $\mathrm{Rh} / \mathrm{N}$ of 0.4 for material M4 from the analytical data, which was close to the expected 0.5 value.

Lower experimental molar ratios for the other materials M1-M3 were found, indicating that partial decomplexation had occurred in the formation of materials by the sol-gel process. The covalent 
incorporation of the organosilane in the hybrid materials was ascertained by ${ }^{29} \mathrm{Si}$ CP MAS solid-state NMR. The ${ }^{29} \mathrm{Si}$ spectra of M1-M3 showed two sets of chemical shifts: T units at around -55 to $-67 \mathrm{ppm}$, resulting from the hydrolysis-condensation of monomers 3 and 4 , and $Q$ units ranging from -90 to $-112 \mathrm{ppm}$, corresponding to the condensed TEOS, as exemplified by the ${ }^{29} \mathrm{Si}$ solid-state NMR of M1 (Figure 2, a). Only the solid-state ${ }^{13} \mathrm{C}$ NMR of M1 was performed (Figure 2, b). Significant absorptions appeared at $13.3 \mathrm{ppm}\left(\mathrm{CH}_{2}-\mathrm{Si}\right)$, which confirmed the covalently bonded ligand to silica, and at $213.3 \mathrm{ppm}$, attributable to the carbenic carbon of the NHC ligand coordinated to the rhodium (C-Rh). In the case of the other materials, M2-M4, the high dilution of the organic moiety in the inorganic matrix precluded the observation of the corresponding absorptions in ${ }^{13} \mathrm{C}$ solidstate NMR. $\mathrm{N}_{2}$-sorption measurements revealed a significant porosity for all the materials and high surface areas ranging from 325 to $512 \mathrm{~m}^{2} \mathrm{~g}^{-1}$ were obtained. The functionalized mesostructured silica M4 prepared by grafting exhibited the highest surface area, with a rather sharp pore size distribution centred at around $59 \AA$ and a type IV isotherm typical for mesoporous materials (Figure 3 ). A powder X-ray diffractogram of M4 confirmed that the original 2D hexagonal mesostructure of the parent silica had not been affected by the grafting (see Supporting Information). However, the BET surface area decreased significantly from $732 \mathrm{~m}^{2} \mathrm{~g}^{-1}$ for parent SBA-15-type silica to $512 \mathrm{~m}^{2} \mathrm{~g}^{-1}$ for $\mathbf{M} 4$, in a clear indication that the precursor 4 had been successfully grafted to the parent silica and had partially filled the pores. For the case of materials derived from sol-gel methodologies, whereas $\mathbf{M} 1$ was found to be a microporous solid (type I isotherm), M2 exhibited a type IV isotherm and the mesoporous material M3 presented a type II isotherm according to the IUPAC rules. ${ }^{[27]}$ In the case of M3 the large amount of nitrogen adsorbed at $\mathrm{p} / \mathrm{p}^{\circ}>0.8$ arise from nitrogen that condenses in the voids between particles (see Supporting Information).

Table 1. Some analytical and textural data of materials M1-M4.

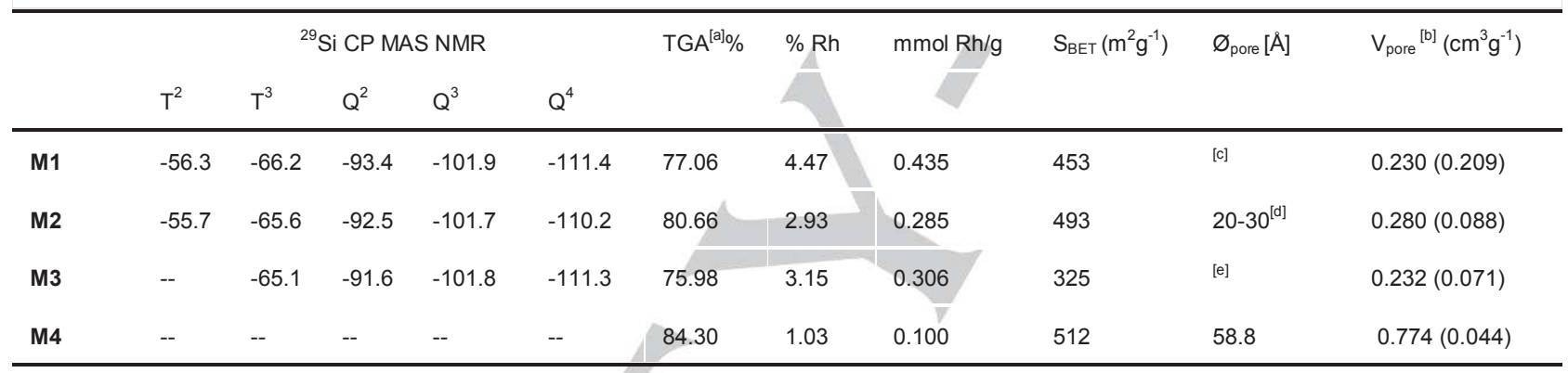

[a] Residual mass measured in the TGA analysis. [b] Total pore volume at $p^{0} p^{0} 0.99\left(p / p^{0} 0.8\right.$ for $\left.M 3\right)$; in brackets contribution of micropores to the $V_{\text {pore }}$. [c] Micropores, type I isotherm. [d] Type IV isotherm, see ESI. [e] Type II isotherm, see text and ESI.

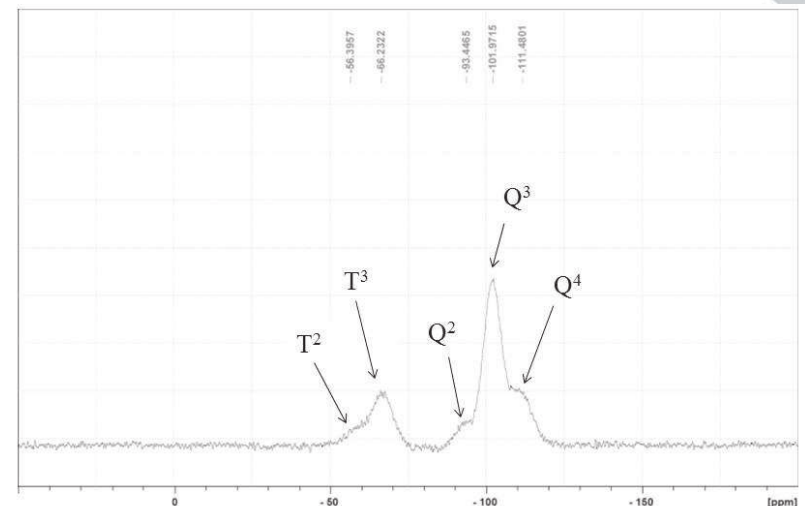

a) ${ }^{29} \mathrm{Si}-\mathrm{SSNMR}$

state NMR spectra for M1.

Figure 2. Solid state NMR spectra for M1.

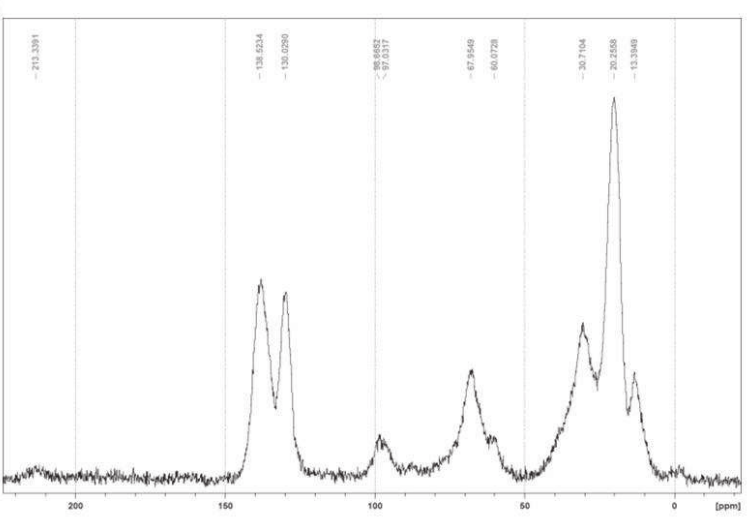

b) ${ }^{13} \mathrm{C}-\mathrm{SSNMR}$

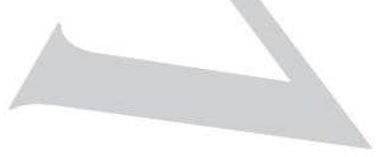



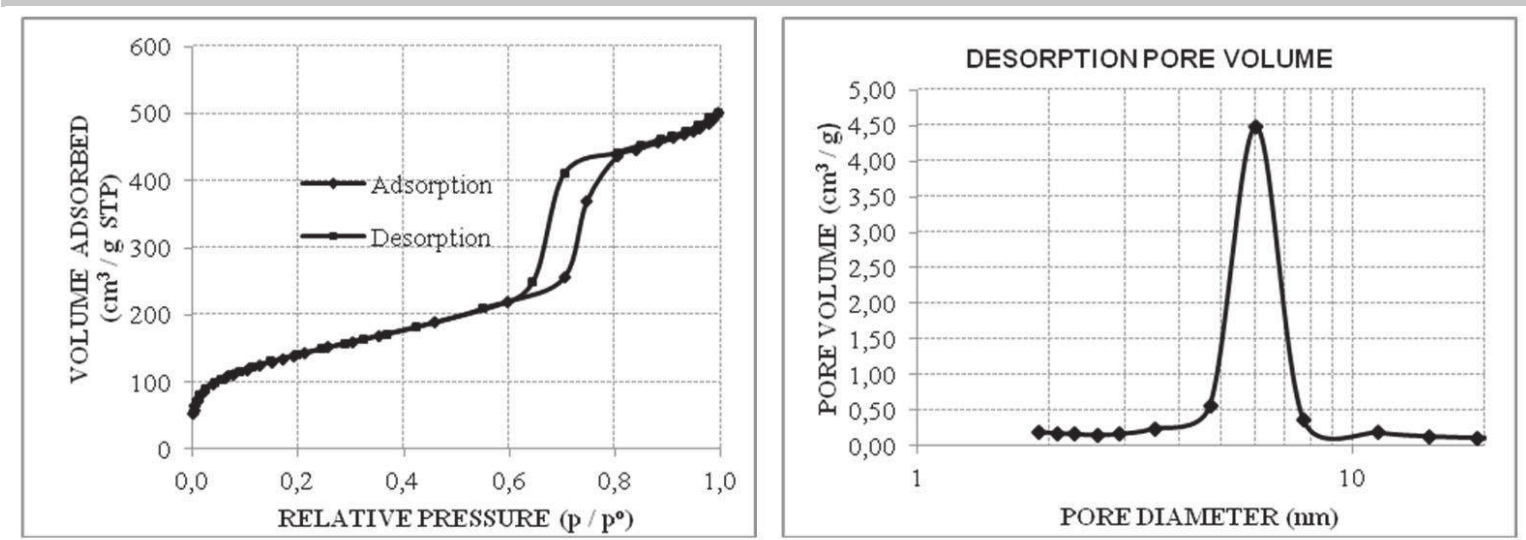

Figure 3. $\mathrm{N}_{2}$ adsorption-desorption isotherm and pore volume distribution of M4

Catalytic activity of the supported catalysts in [2+2+2] cycloaddition reactions

Once the rhodium hybrid silica materials were prepared and characterized, their catalytic activity in the [2+2+2] cycloaddition reaction of alkynes and their recovery and reuse was evaluated.
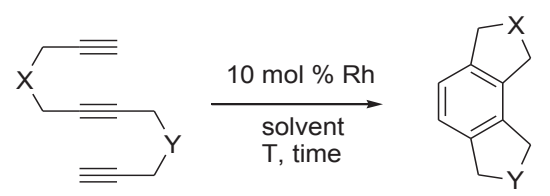

$$
\begin{aligned}
& X, Y=O, 5 \\
& X, Y=N T s, 7 \\
& X=O, Y=N T s, 9
\end{aligned}
$$

$$
\begin{aligned}
& X, Y=O, 6 \\
& X, Y=N T s, 8 \\
& X=O, Y=N T s,
\end{aligned}
$$

Scheme 4. Rh-catalysed $[2+2+2]$ cycloaddition reactions of triynes.

The supported catalysts were tested in the completely intramolecular version of the $[2+2+2]$ cycloaddition reaction of triynes, using the O-tethered triyne 5 (Scheme 4) as a benchmark reaction to establish the best operating conditions. Different solvents and temperatures were tested with this substrate under catalysis by material M2 (Table 2).

First, catalyst loading was set at $10 \mathrm{~mol} \%$ and the reactions were carried out at room temperature using three different solvents (toluene, dichloroethane and ethanol), but no evolution was observed after three hours of reaction (entries 1-3, Table 2). When the reaction temperature was increased to $80^{\circ} \mathrm{C}$ for all solvents, the reactions were completed after 3-5 hours (entries 4 , 6,8 , Table 2). It can be seen that ethanol was clearly the best solvent as the cyclized product 6 was obtained in an almost quantitative yield (entry 8 , Table 2 ). In addition, using ethanol as the solvent, it was possible to recover the catalyst by filtration and highly pure cycloadduct 6 was afforded by evaporation of the organic phase, eliminating the need to use column chromatography. The heterogeneous Rh-complex was then washed with dichloromethane and diethyl ether and used in a subsequent cycle. With this simple methodology, the catalytic system could be reused for four cycles affording good isolated yields of $\mathbf{6}$, although after longer reaction times (entries 8-11,
Table 2). Reusability was also tested using DCE and toluene as the reaction solvents. However the reaction yield dropped in the second cycle (entries 5, 7, Table 2). When a decrease of the catalyst loading to $5 \mathrm{~mol} \%$ was attempted under the same conditions of entry $8\left(\mathrm{EtOH}, 80^{\circ} \mathrm{C}\right)$, incomplete conversion was observed after 30 hours of reaction. We therefore decided to use $\mathrm{EtOH}$ as the solvent at $80^{\circ} \mathrm{C}$ and $10 \mathrm{~mol} \%$ of catalyst for further studies with the other supported catalysts (Table 3 ).

Table 2. Catalytic performance of hybrid silica material M2 in the $[2+2+2]$ cycloaddition of triyne $\mathbf{5}$.

\begin{tabular}{llllll}
\hline Entry & Solvent & $\begin{array}{l}\text { Temp. } \\
\left({ }^{\circ} \mathrm{C}\right)\end{array}$ & Cycle & $\begin{array}{l}\text { Reaction } \\
\text { time }(\mathrm{h})\end{array}$ & $\begin{array}{l}\text { Yield of } 6 \\
(\%)^{[\mathrm{a}]}\end{array}$ \\
\hline 1 & Toluene & 25 & 1 & 3 & 0 \\
2 & DCE & 25 & 1 & 3 & 0 \\
3 & EtOH & 25 & 1 & 3 & 0 \\
4 & Toluene & 80 & 1 & 5 & 61 \\
5 & Toluene & 80 & 2 & 30 & $16^{[\mathrm{b}]}$ \\
6 & DCE & 80 & 1 & 3 & 69 \\
7 & DCE & 80 & 2 & 30 & $10^{[\mathrm{b}]}$ \\
8 & EtOH & 80 & 1 & 3 & 98 \\
9 & EtOH & 80 & 2 & 22 & 84 \\
10 & EtOH & 80 & 3 & 28 & 92 \\
11 & EtOH & 80 & 4 & 33 & 95 \\
\hline
\end{tabular}

[a] Isolated yield. [b] Calculated by ${ }^{1} \mathrm{H}-\mathrm{NMR}$ spectroscopy.

When the other materials were tested in the cycloaddition reaction of triyne $\mathbf{5}, \mathbf{M} 1$ gave the lowest yield (entry 1, Table 3) whereas M3 and M4 showed similar activities (entries 2-3, Table 3). The recyclability of $\mathbf{M} \mathbf{4}$ was then assessed. Material M4 was reused successfully for 6 cycles, although increasing reaction 
times were required upon recycling to achieve full conversions (entries 3-8, Table 3).

The rhodium leaching was determined for the four materials. After complete conversion of $\mathbf{5}$ in the first cycle, the rhodium content in the crude product 6 was determined by ICP-MS analysis and a loss of $5.7 \%$ for M1, $12.2 \%$ for M2, 8.4\% for M3 and $12.15 \%$ for $\mathbf{M} 4$ was found with respect to the initial amount of rhodium added as catalyst. In the case of material M4 the rhodium content was also measured after the second cycle and the loss was found to be $9.76 \%$. A hot filtration test was performed with catalyst M4 in the cycloaddition of triyne 5. M4 was filtered off from the hot reaction mixture under the conditions detailed in Table 3 after 4 minutes of reaction $(17 \%$ GC conversion of 5 ) and the remaining filtrate was made to react under the same conditions. After $2.5 \mathrm{~h}$ the GC conversion increased to $56 \%$ suggesting that a homogeneous pathway plays also a role in the cycloaddition reaction and that homogeneous $\mathrm{Rh}$ species released from the immobilized rhodium system are, at least in part, responsible for the catalysis

Table 3. Catalytic performance of hybrid silica materials M1, M3 and M4 in the $[2+2+2]$ cycloaddition of triyne $5^{\text {[a] }}$

\begin{tabular}{lllll}
\hline Entry & Material & Cycle & $\begin{array}{l}\text { Reaction } \\
\text { time }(\mathrm{h})\end{array}$ & $\begin{array}{l}\text { Yield of 6 } \\
(\%)^{[\mathrm{b}]}\end{array}$ \\
\hline 1 & M1 & 1 & 4 & 77 \\
2 & M3 & 1 & 3 & 85 \\
3 & M4 & 1 & 2.5 & 85 \\
4 & M4 & 2 & 16 & 85 \\
6 & M4 & 3 & 19 & 92 \\
7 & M4 & 4 & 23 & 93 \\
8 & M4 & 5 & 24 & $89^{[\mathrm{cc}]}$ \\
\hline
\end{tabular}

[a] All reactions were carried out in $\mathrm{EtOH}$ at $80^{\circ} \mathrm{C}$. [b] Isolated yield. [c] Yield calculated by ${ }^{1} \mathrm{H}-\mathrm{NMR}$ spectroscopy.

In order to explore the scope of the reaction, the cycloaddition of the $\mathrm{N}$-tosyl-tethered triyne 7 and triyne 9 bearing two different tethers (N-Ts and O) were tested with M4 under the optimized conditions $\left(\mathrm{EtOH}, 80^{\circ} \mathrm{C}\right)$. The results are shown in Table 4.

For both substrates 7 and 9, M4 showed high activity and good recyclability. Almost quantitative yields of 8 and 10 were obtained, respectively, in five successive cycles (Entries 1-5 for 7, entries 6-10 for 9, Table 4), although reaction times substantially increased after the first run.

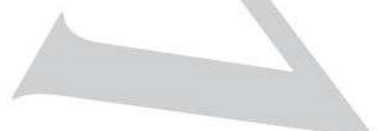

Table 4. Catalytic performance of hybrid silica material M4 in the $[2+2+2]$ cycloaddition of triynes 7 and $\mathbf{9}^{[a]}$

\begin{tabular}{lllll}
\hline Entry & Substrate & Cycle & $\begin{array}{l}\text { Reaction } \\
\text { time }(\mathrm{h})\end{array}$ & $\begin{array}{l}\text { Product, } \\
\left(\text { yield }(\%)^{[\mathrm{b}]}\right)\end{array}$ \\
\hline 1 & $\mathbf{7}$ & 1 & 4 & $\mathbf{8}(99)$ \\
2 & $\mathbf{7}$ & 2 & 16 & $\mathbf{8}(96)$ \\
3 & $\mathbf{7}$ & 3 & 23 & $\mathbf{8}(98)$ \\
4 & $\mathbf{7}$ & 4 & 25 & $\mathbf{8}(98)$ \\
5 & $\mathbf{7}$ & 5 & 55 & $\mathbf{8}(81)^{[\mathrm{c}]}$ \\
6 & $\mathbf{9}$ & 1 & 3 & $\mathbf{1 0}(99)$ \\
7 & $\mathbf{9}$ & 2 & 19 & $\mathbf{1 0}(96)$ \\
8 & $\mathbf{9}$ & 3 & 24 & $\mathbf{1 0}(97)$ \\
9 & $\mathbf{9}$ & 4 & 31 & $\mathbf{1 0}(99)$ \\
10 & $\mathbf{9}$ & 5 & 42 & $\mathbf{1 0}(98)$ \\
\hline
\end{tabular}

[a] All reactions were carried out in $\mathrm{EtOH}$ at $80^{\circ} \mathrm{C}$. [b] Isolated yield. [c] Yield calculated by ${ }^{1} \mathrm{H}-\mathrm{NMR}$ spectroscopy.

In order to shorten the reaction times, especially after the first cycle, we decided to carry out the cycloaddition under microwave irradiation, whose applications in organic synthesis and catalysis as an alternative to conventional heating has increased considerably in recent years. ${ }^{[28]}$ We used this heating system in the cycloaddition of triyne $\mathbf{5}$ to afford tricyclic derivative 6 using catalyst $\mathbf{M} 4$ in $\mathrm{EtOH}$ at $80^{\circ} \mathrm{C}$ (Table 5).

Table 5. Catalytic performance of hybrid silica material M4 under microwave irradiation.

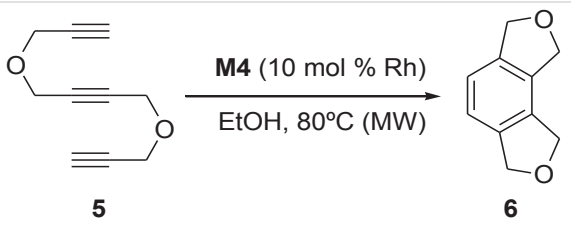

\begin{tabular}{lll}
\hline Cycle & Reaction time $(\min )$. & ${\text { Yield of } \mathbf{6}(\%)^{[a]}}^{[a}$ \\
\hline 1 & 15 & 77 \\
2 & 45 & 84 \\
4 & 80 & 88 \\
\hline
\end{tabular}

[a] Isolated yield. 


\section{Conclusions}

As shown in Table 5 microwave heating efficiently promotes the cycloaddition reaction of triyne $\mathbf{5}$ giving excellent yields of $\mathbf{6}$ in heating. As an example, when comparing Entry 6 of Table 3 with Entry 4 of Table 5, we observe that the reaction time is reduced from 1 day to just 120 minutes in the fourth cycle. In contrast, the rhodium leaching after the first and second run was $14.94 \%$ and $12.57 \%$ respectively, slightly higher than with conventional heating.

Finally, we wanted to test the catalytic activity of material M4 in the partially intramolecular version of the $[2+2+2]$ cycloaddition reaction between several diynes 11 and monoalkynes 12 . We used the same optimized reaction conditions as for the cycloaddition of triynes. Both terminal (Entries 1-4, Table 6) and non-terminal (Entries 5-6, Table 6) diynes with different tethers were active in this process. However, with non-terminal diynes it was necessary to heat the reaction at $110^{\circ} \mathrm{C}$ using $n-\mathrm{BuOH}$ as the solvent as they are less reactive than terminal diynes. Both monosubstituted and disubstituted alkynes 12 also gave good yields of the cycloadducts. In addition, the reusability of M4 was assessed in the reaction of Entry 1 giving an $85 \%$ yield of cycloadduct 13aa in 4.5 hours. significantly shorter reaction times compared with conventional

Rhodium(I) complexes bearing an $\mathrm{N}$-heterocyclic carbene ligand functionalized with either two silylated groups at the saturated carbon backbone (complex 3) or one silylated group at the nitrogen (complex 4) were synthesized by reacting the corresponding imidazolium salts with $[\mathrm{Rh}(\mu-\mathrm{OEt})(\mathrm{COD})]_{2}$. Hybrid silica materials were obtained by cogelification of complexes 3 and 4 with different amounts of tetraethoxysilane, effectively affording hybrid silica materials M1-M3. Monosilylated rhodium complex 4 was also grafted on to the mesostructured silica SBA15 giving material M4. The materials obtained were fully characterized with the standard solid state techniques, making it possible to check that the structure of the catalytic site was maintained in the solid. Furthermore, the rhodium content of the materials was determined by inductively coupled plasma. Their catalytic activity was evaluated in the $[2+2+2]$ cycloaddition reaction of triyne substrates, which afforded tricyclic polysubstituted benzene derivatives. After screening the reaction conditions, ethanol at $80^{\circ} \mathrm{C}$ was found to be optimal for the catalytic system giving excellent yields of cycloadducts. It is possible to separate the catalytic system from the reaction mixture by simple filtration affording an analytically pure product. The catalyst can be reused up to six times without loss of yield of the cycloadducts. The catalytic activity of material M4 was also tested in the cycloaddition reaction between diynes and monoalkynes resulting in good yields of the corresponding cycloadducts. These compounds were obtained with enough purity after filtration of the catalyst and evaporation of the solvent.

cycloaddition between diynes 11 and monoalkynes 12 .
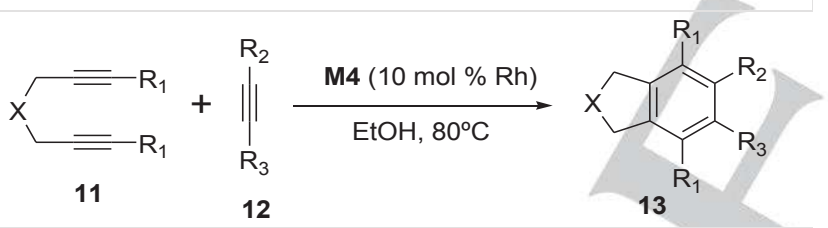

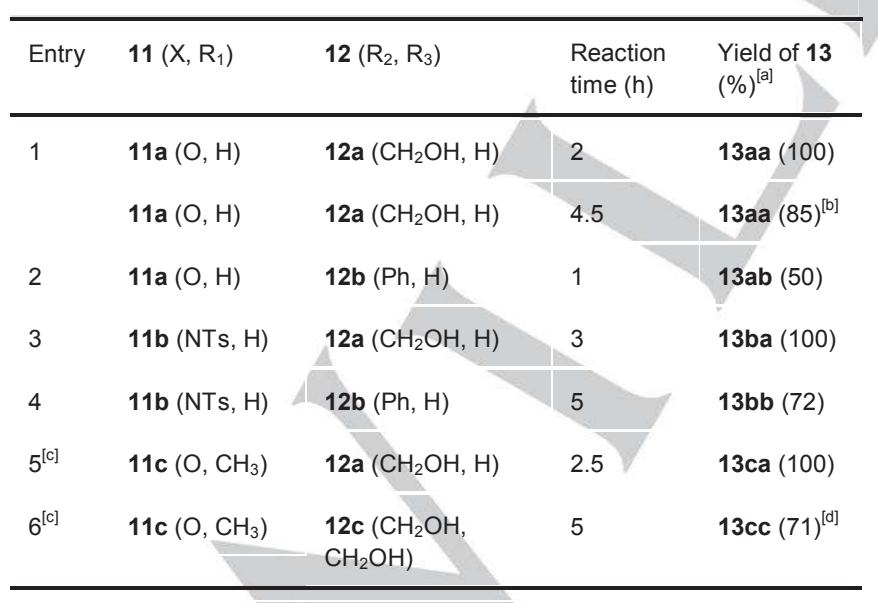

[a] Isolated yield. [b] Second batch. [c] Reaction run in $n-\mathrm{BuOH}$ at $110^{\circ} \mathrm{C}$. [d] Yield calculated by ${ }^{1} \mathrm{H}-\mathrm{NMR}$ spectroscopy.

\section{Experimental Section}

Imidazolium chlorides 1 (see Supporting Information) and $2^{[23]}$ were prepared as described previously by some of us. [Rh( $\mu$-OEt)(COD) $]_{2}{ }^{[29]}$, triynes $5^{[2 \mathrm{~b}]}$ and $7^{[30]}$ were prepared by published methods. Details for the synthesis of triyne $\mathbf{9}$, performed here for the first time, are given in the supplementary material. Mesostructured silica of SBA-15 type was synthesized as previously described. ${ }^{[31]}$

\section{Synthesis of bis-silylated Rh-NHC complex 3.}

Imidazolium salt $1(2.32 \mathrm{mmol})$ and $[\mathrm{Rh}(\mu-\mathrm{OEt})(\mathrm{COD})]_{2}(1.17 \mathrm{mmol})$ were transferred into a Schlenk tube under nitrogen atmosphere and dissolved in anhydrous $\mathrm{CH}_{2} \mathrm{Cl}_{2}(50 \mathrm{~mL})$. The reaction mixture was stirred at room temperature for 15 hours (TLC monitoring). The solvent was evaporated under vacuum and the residue was treated with anhydrous hexanes until the filtrate was colorless. The combined filtrates were then concentrated under vacuum to give Rh complex 3 as an orange gum (1.33 g, 60\% yield). ${ }^{1} \mathrm{H} \mathrm{NMR}\left(400 \mathrm{MHz}, \mathrm{CDCl}_{3}\right) \delta(\mathrm{ppm}): 0.49\left(\mathrm{t},{ }^{3} \mathrm{~J}_{\mathrm{H}, \mathrm{H}}=8.2 \mathrm{~Hz}, 4 \mathrm{H}\right.$, major + minor, $\left.\mathrm{CH}_{2} \mathrm{Si}\right), 1.142\left(\mathrm{t},{ }^{3} \mathrm{~J}_{\mathrm{H}, \mathrm{H}}=7.0 \mathrm{~Hz}, 18 \mathrm{H}\right.$, major, $\left.\mathrm{OCH}_{2} \mathrm{CH}_{3}\right)$, $1.147\left(\mathrm{t},{ }^{3} \mathrm{~J}_{\mathrm{H}, \mathrm{H}}=7.0 \mathrm{~Hz}, 18 \mathrm{H}\right.$, minor, $\left.\mathrm{OCH}_{2} \mathrm{CH}_{3}\right), 1.37-1.76(\mathrm{~m}, 16 \mathrm{H}$, major + minor, $\mathrm{CH}_{2} \mathrm{CH}_{2} \mathrm{CH}_{2} \mathrm{Si}, \mathrm{CH}_{2} \mathrm{CH}_{2} \mathrm{CH}_{2} \mathrm{Si}$, COD-CH $\mathrm{C}_{2}$ ), 2.26 (s, 6H, major, $\mathrm{CH}_{3}$ ), 2.30 (s, 6H, minor, $\mathrm{CH}_{3}$ ), 2.30 (s, 6H, major, $\left.\mathrm{CH}_{3}\right), 2.36(\mathrm{~s}, 6 \mathrm{H}$, minor, $\mathrm{CH}_{3}$ ), 2.53 (s, 6H, minor, $\mathrm{CH}_{3}$ ), 2.63 (s, 6H, major, $\left.\mathrm{CH}_{3}\right), 3.02$ (br abs, $2 \mathrm{H}$, major, COD-CH), 3.32 (br abs, 2H, minor, COD-CH), 3.683 (q, ${ }^{3} \mathrm{~J}_{\mathrm{H}, \mathrm{H}}=7.0 \mathrm{~Hz}, 12 \mathrm{H}$, major, $\left.\mathrm{OCH}_{2} \mathrm{CH}_{3}\right), 3.687\left(\mathrm{q},{ }^{3} \mathrm{~J}_{\mathrm{H}, \mathrm{H}}=7.0 \mathrm{~Hz}, 12 \mathrm{H}\right.$, minor, $\left.\mathrm{OCH}_{2} \mathrm{CH}_{3}\right), 4.01-4.09(\mathrm{~m}, 2 \mathrm{H}$, major + minor, $\mathrm{NCH}$ ), 4.43 (br abs, $2 \mathrm{H}$, major + minor, COD-CH), 6.90 (s, 2H, major, Ar), 6.93 (s, 2H, minor, Ar), 6.94 (s, $2 \mathrm{H}$, minor, $\mathrm{Ar}$ ), 7.00 (s, $2 \mathrm{H}$, major, Ar). ${ }^{13} \mathrm{C} \mathrm{NMR}(75 \mathrm{MHz}$, 
$\left.\mathrm{CDCl}_{3}\right) \delta$ (ppm): $10.6\left(\mathrm{CH}_{2} \mathrm{Si}\right.$, major $), 10.7\left(\mathrm{CH}_{2} \mathrm{Si}\right.$, minor $), 18.2$ $\left(\mathrm{OCH}_{2} \mathrm{CH}_{3}\right.$, major + minor $), 19.1\left(\mathrm{CH}_{3}\right.$, major $), 19.8\left(\mathrm{CH}_{3}\right.$, minor $), 20.2$ $\left(\mathrm{CH}_{3}\right.$, minor $), 20.6\left(\mathrm{CH}_{2}\right.$, minor $), 20.7\left(\mathrm{CH}_{2}\right.$, major $), 20.9\left(\mathrm{CH}_{3}\right.$, major $)$, $21.0\left(\mathrm{CH}_{3}\right.$, minor $), 21.7\left(\mathrm{CH}_{3}\right.$, major $), 27.9\left(\mathrm{CH}_{2}\right.$, major $), 28.0\left(\mathrm{CH}_{2}\right.$, minor $)$ 30.8 (COD- $\mathrm{CH}_{2}$, minor), 31.2 (COD- $\mathrm{CH}_{2}$, major), 32.5 (COD- $\mathrm{CH}_{2}$, major), $32.7\left(\mathrm{COD}-\mathrm{CH}_{2}\right.$, minor), $58.2\left(\mathrm{OCH}_{2} \mathrm{CH}_{3}\right.$, major + minor), $65.3(\mathrm{NCH}$, minor), $66.1\left(\mathrm{NCH}\right.$, major), $67.1\left(\mathrm{~d},{ }^{1} J_{\mathrm{Rh}, \mathrm{C}}=14.5 \mathrm{~Hz}, \mathrm{COD}-\mathrm{CH}\right.$, major), $68.3\left(\mathrm{~d},{ }^{1} J_{\mathrm{Rh}-\mathrm{C}}=14.0 \mathrm{~Hz}\right.$, COD-CH, minor), $96.5\left(\mathrm{~d},{ }^{1} J_{\mathrm{Rh}-\mathrm{C}}=7.0 \mathrm{~Hz}, \mathrm{COD}-\right.$ $\mathrm{CH}$, minor), 96.9 (d, ${ }^{1} \mathrm{~J}_{\mathrm{Rh}, \mathrm{C}}=6.9 \mathrm{~Hz}, \mathrm{COD}-\mathrm{CH}$, major), $128.3(\mathrm{CH}-\mathrm{Ar}$, minor), 128.5 ( $\mathrm{CH}-\mathrm{Ar}$, major), 129.9 ( $\mathrm{CH}-\mathrm{Ar}$, minor), 130.0 (CH-Ar, major), 134.9 (C-Ar, major), 136.1 (C-Ar, minor), 136.1 (C-Ar, major), 136.5 (CAr, minor), 137.2 (C-Ar, major + minor), 138.2 (C-Ar, minor), 139.3 (C-Ar, major), $213.2\left(\mathrm{~d},{ }^{1} J_{\mathrm{Rh}, \mathrm{C}}=48.0 \mathrm{~Hz}, \mathrm{Rh}-\mathrm{C}_{\text {carbene, }}\right.$ minor + major). ESI-HRMS $(\mathrm{m} / \mathrm{z})$ : calculated for $\left[\mathrm{C}_{47} \mathrm{H}_{78} \mathrm{O}_{6} \mathrm{~N}_{2} \mathrm{RhSi}_{2}\right]^{+}$: 925.4448 ; found: 925.4470 .

\section{Synthesis of monosilylated Rh-NHC complex 4}

Prepared according to the method described for complex 3 with the following specific conditions: Imidazolium salt 2 (3.87 mmol), $[\mathrm{Rh}(\mu-$ OEt)(COD)] $]_{2}(1.95 \mathrm{mmol})$, anhydrous $\mathrm{CH}_{2} \mathrm{Cl}_{2}(25 \mathrm{~mL})$, work up with anhydrous diethyl ether. Yellow solid $(2.24 \mathrm{~g}, 91 \%$ yield $) .{ }^{1} \mathrm{H}$ NMR $\left(400 \mathrm{MHz}, \mathrm{CDCl}_{3}\right) \delta(\mathrm{ppm}): 0.77\left(\mathrm{t},{ }^{3} \mathrm{~J}_{\mathrm{H}, \mathrm{H}}=8.4 \mathrm{~Hz}, 2 \mathrm{H}, \mathrm{CH}_{2} \mathrm{Si}\right), 1.25$ (t, $\left.{ }^{3} \mathrm{~J}_{\mathrm{H}, \mathrm{H}}=7.0 \mathrm{~Hz}, 9 \mathrm{H}, \mathrm{OCH}_{2} \mathrm{CH}_{3}\right), 1.46-1.70\left(\mathrm{~m}, 2 \mathrm{H} \mathrm{CH}_{2} \mathrm{CH}_{2} \mathrm{CH}_{2}+2 \mathrm{H} \mathrm{COD}-\right.$ $\mathrm{CH}_{2}$ ), 1.82 (s, 3H, $\left.\mathrm{CH}_{3}\right), 1.96-2.20$ (m, 4H COD- $\mathrm{CH}_{2}+2 \mathrm{H} \mathrm{NCH}$ ), 2.37 (s, $\left.3 \mathrm{H}, \mathrm{CH}_{3}\right), 2.43\left(\mathrm{~s}, 3 \mathrm{H}, \mathrm{CH}_{3}\right), 2.96\left(\mathrm{~m}, 1 \mathrm{H}, \mathrm{COD}-\mathrm{CH}_{2}\right), 3.43(\mathrm{~m}, 1 \mathrm{H}, \mathrm{COD}$ $\left.\mathrm{CH}_{2}\right), 3.86\left(\mathrm{q},{ }^{3} \mathrm{~J}_{\mathrm{H}, \mathrm{H}}=7.0 \mathrm{~Hz}, 6 \mathrm{H}, \mathrm{OCH}_{2} \mathrm{CH}_{3}\right), 4.19(\mathrm{~m}, 1 \mathrm{H}, \mathrm{COD}-\mathrm{CH})$, 4.76-4.88 (m, 2H, COD-CH), $5.29(\mathrm{~m}, 1 \mathrm{H}, \mathrm{COD}-\mathrm{CH}), 6.73\left(\mathrm{~d},{ }^{3} \mathrm{~J}_{\mathrm{H}, \mathrm{H}}=1.8\right.$ $\mathrm{Hz}, 1 \mathrm{H}$, imidazole), $6.90(\mathrm{br} \mathrm{s}, 1 \mathrm{H}, \mathrm{Ar}), 7.03\left(\mathrm{~d},{ }^{3} \mathrm{~J}_{\mathrm{H}, \mathrm{H}}=1.8 \mathrm{~Hz}, 1 \mathrm{H}\right.$, imidazole), 7.09 (br s, $1 \mathrm{H}, \mathrm{Ar}) \cdot{ }^{13} \mathrm{C} \mathrm{NMR}\left(75 \mathrm{MHz}, \mathrm{CDCl}_{3}\right) \delta(\mathrm{ppm}): 7.83$ $\left(\mathrm{CH}_{2} \mathrm{Si}\right), 17.7,18.3\left(\mathrm{OCH}_{2} \mathrm{CH}_{3}\right), 19.7,21.0,24.6,27.9\left(\mathrm{COD}-\mathrm{CH}_{2}\right), 29.1$ $\left(\mathrm{COD}-\mathrm{CH}_{2}\right), \quad 31.5\left(\mathrm{COD}-\mathrm{CH}_{2}\right), \quad 34.0\left(\mathrm{COD}-\mathrm{CH}_{2}\right), \quad 54.0\left(\mathrm{NCH}_{2}\right), \quad 58.5$ $\left(\mathrm{OCH}_{2} \mathrm{CH}_{3}\right), 67.4\left(\mathrm{~d},{ }^{1} J_{\mathrm{Rh}, \mathrm{C}}=14.7 \mathrm{~Hz}, \mathrm{COD}-\mathrm{CH}\right), 68.3\left(\mathrm{~d},{ }^{1} \mathrm{~J}_{\mathrm{Rh}, \mathrm{C}}=14.2 \mathrm{~Hz}\right.$ COD-CH), $96.7\left(\mathrm{~d},{ }^{1} J_{\mathrm{Rh}, \mathrm{C}}=7.3 \mathrm{~Hz}, \mathrm{COD}-\mathrm{CH}\right), 96.9\left(\mathrm{~d},{ }^{1} J_{\mathrm{Rh}, \mathrm{C}}=7.1 \mathrm{~Hz}\right.$, COD-CH), 120.9 (CH-imidazole), 122.8(CH-imidazole), $128.0(\mathrm{CH}-\mathrm{Ar})$, 129.5 (CH-Ar), 134.3 (C-Ar), 136.2 (C-Ar), 137.2 (C-Ar), 138.5 (C-Ar), $181.6\left(\mathrm{~d},{ }^{1} J_{\mathrm{Rh}, \mathrm{C}}=51.5 \mathrm{~Hz}, \mathrm{Rh}-\mathrm{C}_{\text {carbene }}\right)$. ESI-HRMS (m/z): calculated for $\left[\mathrm{C}_{29} \mathrm{H}_{46} \mathrm{O}_{3} \mathrm{~N}_{2} \mathrm{RhSi}\right]^{+}$: 601.2327; found: 601.2333 .

\section{Preparation of materials}

Material M1: A mixture of TBAF $(0.16 \mathrm{~mL}$ of $1 \mathrm{M}$ solution in anhydrous THF, $0.160 \mathrm{mmol}$ ) and doubly deionized water (milliQ) $(0.745 \mathrm{~mL}, 41.3$ $\mathrm{mmol}$ ) in anhydrous DMF $(3 \mathrm{~mL})$ was added to a stirred solution of complex $3(0.64 \mathrm{~g}, 0.6 \mathrm{mmol})$ and TEOS $(1.70 \mathrm{~mL}, 8.57 \mathrm{mmol})$ in anhydrous DMF $(10 \mathrm{~mL})$ under nitrogen atmosphere. The reaction mixture was stirred at room temperature for 5 minutes. A gel was formed within 1 hour and was left to age at room temperature under nitrogen atmosphere for 6 days. This gel was pulverized, filtered and washed with $\mathrm{EtOH}(3 \times 10 \mathrm{~mL})$, acetone $(3 \times 10 \mathrm{~mL})$ and anhydrous $\mathrm{Et}_{2} \mathrm{O}(3 \times 10 \mathrm{~mL})$. In order to completely remove residual DMF, the powder obtained was left in a soxhlet apparatus for 48 hours with chloroform. The powder was dried overnight at $40^{\circ} \mathrm{C}$ under vacuum to afford material $\mathbf{M} 1$ as an orange powder $(1.25 \mathrm{~g}) .{ }^{29} \mathrm{Si}-\mathrm{CP}-\mathrm{MAS}$ NMR $(79.5 \mathrm{MHz}) \delta(\mathrm{ppm}):-111.4\left(\mathrm{Q}^{4}\right)$, $101.9\left(\mathrm{Q}^{3}\right)$, -93.4 $\left(\mathrm{Q}^{2}\right),-66.2\left(\mathrm{~T}^{3}\right),-56.3\left(\mathrm{~T}^{2}\right) .{ }^{13} \mathrm{C}$-CP-MAS NMR $(100.6$ $\mathrm{MHz}) \delta(\mathrm{ppm}): 13.3,20.2,30.7,60.0,67.9,97.0,98.6,130.0,138.5$, 213.3. BET $S_{B E T}: 453 \mathrm{~m}^{2} / \mathrm{g}$; type I sorption isotherm; TGA (air, 30 to $700^{\circ} \mathrm{C}$ ) residual mass $77.06 \%$. EA calculated for $\mathrm{C}_{35} \mathrm{H}_{48} \mathrm{~N}_{2} \mathrm{ClRh} \cdot 2 \mathrm{SiO}_{1.5} \cdot 14 \mathrm{SiO}_{2}$ (considering complete condensation): $1.77 \% \mathrm{~N}, 26.60 \% \mathrm{C}, 3.06 \% \mathrm{H}, 6.51 \% \mathrm{Rh}$; found: $1.01 \% \mathrm{~N}, 15.45 \% \mathrm{C}$, $2.65 \% \mathrm{H}, 4.47 \% \mathrm{Rh}$

Material M2: Prepared according to the method described for material M1 with the following specific conditions: TBAF $(0.215 \mathrm{~mL}, 0.215 \mathrm{mmol})$, milliQ water $(1.5 \mathrm{~mL}, 83.3 \mathrm{mmol})$, complex $3(0.64 \mathrm{~g}, 0.6 \mathrm{mmol})$, TEOS
(4.6 $\mathrm{mL}, 20.1 \mathrm{mmol})$. M2 was obtained as an orange powder $(1.91 \mathrm{~g})$. ${ }^{29} \mathrm{Si}-\mathrm{CP}-\mathrm{MAS}$ NMR $(79.5 \mathrm{MHz}) \delta(\mathrm{ppm}):-110.2\left(\mathrm{Q}^{4}\right),-101.7\left(\mathrm{Q}^{3}\right),-92.5$ $\left(Q^{2}\right)$, -65.6 $\left(\mathrm{T}^{3}\right), \quad-55.7\left(\mathrm{~T}^{2}\right)$. BET $\mathrm{S}_{\mathrm{BET}}: 493 \mathrm{~m}^{2} / \mathrm{g}$; type IV sorption isotherm; TGA (air, 30 to $700^{\circ} \mathrm{C}$ ) residual mass $80.66 \%$. EA calculated for $\mathrm{C}_{35} \mathrm{H}_{48} \mathrm{~N}_{2} \mathrm{ClRh} \cdot 2 \mathrm{SiO}_{1.5} \cdot 30 \mathrm{SiO}_{2}$ (considering complete condensation): $1.10 \% \mathrm{~N}, 16.54 \% \mathrm{C}, 1.90 \% \mathrm{H}, 4.05 \% \mathrm{Rh}$; found: $0.83 \% \mathrm{~N}, 10.65 \% \mathrm{C}$ $2.33 \% \mathrm{H}, 2.93 \% \mathrm{Rh}$.

Material M3: Prepared according to the method described for material M1 with the following specific conditions: TBAF $(0.350 \mathrm{~mL}, 0.350 \mathrm{mmol})$, milliQ water $(2.5 \mathrm{~mL}, 83.3 \mathrm{mmol})$, EtOH as solvent, complex $4(0.72 \mathrm{~g}$, $1.13 \mathrm{mmol})$, TEOS $(7.7 \mathrm{~mL}, 33.9 \mathrm{mmol})$. M3 was obtained as a paleyellow powder $(2.64 \mathrm{~g}) .{ }^{29} \mathrm{Si}-\mathrm{CP}-\mathrm{MAS}$ NMR $(79.5 \mathrm{MHz}) \delta(\mathrm{ppm}):-111.3$ $\left(Q^{4}\right)$, -101.8 $\left(Q^{3}\right)$, -91.6 $\left(Q^{2}\right)$, -65.1 $\left(T^{3}\right)$. BET S $S_{\text {BET: }} 325 \mathrm{~m}^{2} / \mathrm{g}$; type II sorption isotherm; TGA (air, 30 to $700^{\circ} \mathrm{C}$ ) residual mass $75.98 \%$. EA calculated for $\mathrm{C}_{23} \mathrm{H}_{31} \mathrm{~N}_{2} \mathrm{CIRh} \cdot \mathrm{SiO}_{1.5} \cdot 30 \mathrm{SiO}_{2}$ (considering complete condensation): $1.20 \% \mathrm{~N}, 11.86 \% \mathrm{C}, 1.34 \% \mathrm{H}, 4.42 \% \mathrm{Rh}$; found: $1.18 \% \mathrm{~N}$, $12.19 \%$ C, $2.29 \% \mathrm{H}, 3.15 \% \mathrm{Rh}$.

Material M4. A mixture of complex $4(0.21 \mathrm{~g}, 0.34 \mathrm{mmol})$ and mesostructured silica SBA-15 $(1.96 \mathrm{~g}, 32.70 \mathrm{mmol})$ was transferred into a Schlenk tube equipped with a Dean-Stark apparatus in anhydrous toluene $(40 \mathrm{~mL})$. The reaction mixture was stirred and refluxed for 24 hours. The resulting suspension was filtered and the powder obtained was washed with $\mathrm{EtOH}(3 \times 20 \mathrm{~mL})$, acetone $(3 \times 20 \mathrm{~mL})$ and anhydrous $\mathrm{Et}_{2} \mathrm{O}(3 \times 20 \mathrm{~mL})$. The powder was dried overnight at $40^{\circ} \mathrm{C}$ under vacuum. M4 was obtained as a white powder $(1.76 \mathrm{~g})$. BET $\mathrm{S}_{\mathrm{BET}}: 512 \mathrm{~m}^{2} / \mathrm{g}$; pore diameter (BJH): $58.8 \AA$ (desorption); type IV sorption isotherm; pore volume (BJH): $0.692 \mathrm{~cm}^{3} / \mathrm{g}$ (desorption). TGA (air, 30 to $700^{\circ} \mathrm{C}$ ) residual mass $84.30 \%$. EA found: $0.55 \% \mathrm{~N}, 5.39 \% \mathrm{C}, 1.00 \% \mathrm{H}, 1.03 \% \mathrm{Rh}$.

\section{General procedure for $[2+2+2]$ cycloaddition reactions.}

The reactions were carried out in a Carousel multireactor. The alkynes $(0.1 \mathrm{mmol})$, the material $(0.01 \mathrm{mmol} \mathrm{Rh})$ and $\mathrm{EtOH}(3 \mathrm{~mL})$ were transferred into the reaction tubes of the reactor and the reaction mixtures were stirred at $80^{\circ} \mathrm{C}$ (external temperature). When there was no presence of starting material (TLC or GC monitoring), the stirring was stopped and the reaction mixture was allowed to cool down. The solution was then filtered. The recovered catalyst was washed with $\mathrm{CH}_{2} \mathrm{Cl}_{2}(3 \times 3$ $\mathrm{mL})$ and $\mathrm{Et}_{2} \mathrm{O}(2 \times 3 \mathrm{~mL})$, dried under vacuum and directly used in the next cycle. The filtrates were concentrated under reduced pressure to afford the corresponding product.

1,3,6,8-Tetrahydro-2,7-dioxa-as-indacene, $6 .{ }^{[2 \mathrm{~b}]}$ Colourless solid. ${ }^{1} \mathrm{H}$ NMR $\left(400 \mathrm{MHz}, \mathrm{CDCl}_{3}\right) \delta$ (ppm): 5.03 (br s, $4 \mathrm{H}, \mathrm{CH}_{2} \mathrm{O}$ ), 5.12 (br s, $4 \mathrm{H}, \mathrm{CH}_{2} \mathrm{O}$ ), $7.14(\mathrm{~s}, 2 \mathrm{H}, \mathrm{Ar})$

2,7-Bis(p-toluenesulfonyl)-1,3,6,8-tetrahydro-2,7-diaza-as-indacene, 8. $^{\text {[30] }}$ Colourless solid. ${ }^{1} \mathrm{H}$ NMR $\left(300 \mathrm{MHz}, \mathrm{CDCl}_{3}\right) \delta(\mathrm{ppm}): 2.40$ (s, $\left.6 \mathrm{H}, \mathrm{CH}_{3}\right)$, $4.45\left(\mathrm{~s}, 4 \mathrm{H}, \mathrm{CH}_{2}\right), 4.57\left(\mathrm{~s}, 4 \mathrm{H}, \mathrm{CH}_{2}\right), 7.04(\mathrm{~s}, 2 \mathrm{H}, \mathrm{Ar}), 7.31\left(\mathrm{~d},{ }^{3} \mathrm{~J}_{\mathrm{H}, \mathrm{H}}=8.0\right.$ $\mathrm{Hz}, 4 \mathrm{H}, \mathrm{Ts}), 7.74\left(\mathrm{~d},{ }^{3} \mathrm{~J}_{\mathrm{H}, \mathrm{H}}=8.0 \mathrm{~Hz}, 4 \mathrm{H}, \mathrm{Ts}\right)$.

7-(p-toluenesulfonyl)-2-oxa-7-aza-1,3,6,8-tetrahydro-as-indacene, $\quad 10$ Colourless solid. M.p. $142-144^{\circ} \mathrm{C}$ (dec.). ${ }^{1} \mathrm{H}$ NMR $\left(300 \mathrm{MHz}, \mathrm{CDCl}_{3}\right) \delta$ (ppm): 2.40 (s, $\left.3 \mathrm{H}, \mathrm{CH}_{3}\right), 4.50$ (br s, $2 \mathrm{H}, \mathrm{CH}_{2}-\mathrm{NTs}$ ), 4.62 (br s, $2 \mathrm{H}, \mathrm{CH}_{2-}$ NTs), 4.97 (br s, 2H, CH $\mathrm{CH}_{2} \mathrm{O}$ ), 5.06 (br s, 2H, $\mathrm{CH}_{2}-\mathrm{O}$ ), 7.05-7.12 (m, $2 \mathrm{H}$, $\mathrm{CH}-\mathrm{Ar}), 7.31\left(\mathrm{~d},{ }^{3} \mathrm{~J}_{\mathrm{H}, \mathrm{H}}=8.1 \mathrm{~Hz}, 2 \mathrm{H}, \mathrm{Ar}-\mathrm{Ts}\right), 7.76\left(\mathrm{~d},{ }^{3} \mathrm{~J}_{\mathrm{H}, \mathrm{H}}=8.1 \mathrm{~Hz}, 2 \mathrm{H}\right.$, Ar-Ts). ${ }^{13} \mathrm{C}$ NMR $\left(75 \mathrm{MHz}, \mathrm{CDCl}_{3}\right) \delta(\mathrm{ppm}): 21.8\left(\mathrm{CH}_{3}-\mathrm{Ts}\right), 52.6\left(\mathrm{CH}_{2^{-}}\right.$ NTs), $53.7\left(\mathrm{CH}_{2}\right.$-NTs), $72.3\left(\mathrm{CH}_{2}-\mathrm{O}\right), 73.7\left(\mathrm{CH}_{2}-\mathrm{O}\right), 120.7(\mathrm{CH}-\mathrm{Ar}), 121.9$ (CH-Ar), 127.9 (CH-Ts), 129.7 (C-Ar), 130.2 (CH-Ts), 133.9 (C-Ar), 134.0 (C-Ar), 135.9 (C-Ts), 139.5 (C-Ar), 144.1 (C-Ts). IR (ATR) v $\left(\mathrm{cm}^{-1}\right): 2857$, 1340, 1156. ESI-MS (m/z): $316\left[\mathrm{M}+\mathrm{H}^{+}, 338[\mathrm{M}+\mathrm{Na}]^{+}, 653[2 \mathrm{M}+\mathrm{H}]^{+}\right.$. 
ESI-HRMS (m/z): calculated for $\left[\mathrm{C}_{17} \mathrm{H}_{17} \mathrm{O}_{3} \mathrm{NS}+\mathrm{Na}\right]^{+}: 338.0809$; found: 338.0821

5-hydroxymethylphthalan, 13aa. ${ }^{[32]}$ Colourless solid. ${ }^{1} \mathrm{H}$ NMR $(300 \mathrm{MHz}$, $\left.\mathrm{CDCl}_{3}\right) \delta$ (ppm): 4.69 (s, 2H, CH $\left.\mathrm{H}_{2} \mathrm{OH}\right), 5.09$ (s, $\left.5 \mathrm{H}, \mathrm{CH}_{2} \mathrm{O}+\mathrm{OH}\right), 7.19$ 7.27 (m, 3H, CH-Ar).

5-phenylphthalan, 13ab. ${ }^{[32]}$ Colourless solid. ${ }^{1} \mathrm{H}$ NMR $\left(300 \mathrm{MHz}, \mathrm{CDCl}_{3}\right) \delta$ (ppm): 5.17 (s, 4H, $\left.\mathrm{CH}_{2} \mathrm{O}\right), 7.29-7.60$ (m, 8H, CH-Ar).

5-hydroxymethyl-2-(p-toluenesulfonyl)-1,3-dihydroisoindole, $\quad$ 13ba. ${ }^{[33]}$ Colourless solid. ${ }^{1} \mathrm{H}$ NMR $\left(300 \mathrm{MHz}, \mathrm{CDCl}_{3}\right) \delta(\mathrm{ppm}): 2.39\left(\mathrm{~s}, 3 \mathrm{H}, \mathrm{CH}_{3}\right)$ 4.56 (s, 4H, CH $\mathrm{CH}_{2} \mathrm{NTs}$ ), 4.64 (s, 2H, CH $\mathrm{CH}_{2} \mathrm{OH}$ ), 7.11-7.23 (m, 3H, CH-Ar), $7.30\left(\mathrm{~d},{ }^{3} \mathrm{~J}_{\mathrm{H}, \mathrm{H}}=8.1 \mathrm{~Hz}, 2 \mathrm{H}, \mathrm{Ts}\right), 7.74\left(\mathrm{~d},{ }^{3} \mathrm{~J}_{\mathrm{H}, \mathrm{H}}=8.1 \mathrm{~Hz}, 2 \mathrm{H}, \mathrm{Ts}\right)$.

5-phenyl-2-(p-toluenesulfonyl)-1,3-dihydroisoindole, 13bb. ${ }^{[32]}$ Colourless solid. ${ }^{1} \mathrm{H}$ NMR $\left(300 \mathrm{MHz}, \mathrm{CDCl}_{3}\right) \delta$ (ppm): $2.43\left(\mathrm{~s}, 3 \mathrm{H}, \mathrm{CH}_{3}\right), 4.69$ (br abs, $4 \mathrm{H}, \mathrm{CH}_{2}-\mathrm{NTs}$ ), 7.25 (d, $\left.{ }^{3} \mathrm{~J}_{\mathrm{H}, \mathrm{H}}=8.1 \mathrm{~Hz}, 1 \mathrm{H}, \mathrm{CH}-\mathrm{Ar}\right), 7.30-7.56(\mathrm{~m}, 9 \mathrm{H})$, $7.80\left(\mathrm{~d},{ }^{3} \mathrm{~J}_{\mathrm{H}, \mathrm{H}}=8.3 \mathrm{~Hz}, 2 \mathrm{H}, \mathrm{Ts}\right)$.

5-hydroxymethyl-4,7-dimethylphthalan, 13ca. ${ }^{[2 \mathrm{~b}]}$ Colourless solid. ${ }^{1} \mathrm{H}$ NMR (300MHz, $\left.\mathrm{CDCl}_{3}\right) \delta(\mathrm{ppm}): 2.21\left(\mathrm{~s}, 6 \mathrm{H}, \mathrm{CH}_{3}\right), 4.69\left(\mathrm{~s}, 3 \mathrm{H}, \mathrm{CH}_{2} \mathrm{OH}\right)$, $5.11\left(\mathrm{~s}, 4 \mathrm{H}, \mathrm{CH}_{2} \mathrm{O}\right), 7.07$ (s, $1 \mathrm{H}, \mathrm{CH}-\mathrm{Ar}$ )

5,6-dihydroxymethyl-4,7-dimethylphthalan, 13cc. ${ }^{[2 \mathrm{~b}]}$ Colourless solid. ${ }^{1} \mathrm{H}$ NMR (400MHz, DMSO- $\left.\mathrm{d}_{6}\right) \delta(\mathrm{ppm}): 2.18\left(\mathrm{~s}, 6 \mathrm{H}, \mathrm{CH}_{3}\right), 4.56\left(\mathrm{~d},{ }^{3} \mathrm{~J}_{\mathrm{H}, \mathrm{H}}=5.2\right.$ $\left.\mathrm{Hz}, 4 \mathrm{H}, \mathrm{CH}_{2} \mathrm{OH}\right), 4.71\left(\mathrm{t},{ }^{3} \mathrm{~J}_{\mathrm{H}, \mathrm{H}}=5.2 \mathrm{~Hz}, 2 \mathrm{H}, \mathrm{OH}\right), 5.01\left(\mathrm{~s}, 4 \mathrm{H}, \mathrm{CH}_{2} \mathrm{O}\right)$.

\section{Acknowledgements}

Financial support from MICINN of Spain (CTQ2011-23121, CTQ2009-07881, CTQ2012-32436, CTQ2011-22649, CSD2007-00006) and "Generalitat de Catalunya" (2009SGR637, 2009SGR1441, and a predoctoral grant to M.Fernández) is acknowledged. M. Ferré thanks the Universitat Autònoma de Barcelona for a predoctoral scholarship. We would like to thank Mònica Iglesias and Enriqueta Anticó for ICP measurement and Xavier Cattoën for helpful comments.

Keywords: Rhodium • Carbenes • Supported catalysts • Sol-gel processes $\cdot$ Cycloadditions

[1] For a monography, see: Transition-Metal-Mediated Aromatic Ring Construction, (Ed.: K. Tanaka) John Wiley \& Sons, Hoboken, 2013. For recent reviews, see: a) S. Saito, Y. Yamamoto, Chem. Rev. 2000, 100 2901-2915; b) S. Kotha, E. Brahmachary, K. Lahiri, Eur. J. Org. Chem. 2005, 4741-4767; c) Y. Yamamoto, Curr. Org. Chem. 2005, 9, 503-519; d) V. Gandon, C. Aubert, M. Malacria, Chem. Commun. 2006, 2209217; e) P.R. Chopade, J. Louie, Adv. Synth. Catal. 2006, 348, $2307-$ 2327; f) N. Agenet, O. Buisine, F. Slowinski, V. Gandon, C. Aubert, M. Malacria, Org. React. 2007, 68, 1-291; g) B. Heller, M. Hapke, Chem. Soc. Rev. 2007, 36, 1085-1094; h) K. Tanaka, Synlett 2007, $1977-$ 1993; i) J.A. Varela, C. Saá, Synlett 2008, 2571-2578; j) T. Shibata, K. Tsuchikama, Org. Biomol. Chem 2008, 6, 1317-1323; k) K. Tanaka, Chem. Asian J. 2009, 4, 508-518; I) B.R. Galan, T. Rovis, Angew. Chem. Int. Ed. 2009, 48, 2830-2834; m) S. Perreault, T. Rovis, Chem. Soc. Rev. 2009, 38, 3149-3159; n) L. Zhou, S. Li, K.-I. Kanno, T Takahashi, Heterocycles 2010, 80, 725-738; o) A. Pla-Quintana, A. Roglans, Molecules 2010, 15, 9230-9251; p) P.A. Inglesby, P.A. Evans,
Chem. Soc. Rev. 2010, 39, 2791-2805; q) M.R. Shaaban, R. El-Sayed, A.H.M. Elwahy, Tetrahedron 2011, 67, 6095-6130; r) S. Okamoto, Heterocycles 2012, 85, 1579-1602; s) K. Tanaka, Heterocycles 2012, 85, 1017-1043; t) R. Hua, M.V.A. Abrenica, P. Wang, Curr. Org. Chem. 2011, 15, 712-729; u) G. Domínguez, J. Pérez-Castells, Chem. Soc. Rev. 2011, 40, 3430-3444; w) N. Weding, M. Hapke, Chem. Soc. Rev. 2011, 40, 4525-4538; y) D.L.J. Broere, E. Ruijter, Synthesis 2012, 2639-2672.

[2] a) R. Grigg, R. Scott, P. Stevenson, Tetrahedron Lett. 1982, 23, 26912692; b) R. Grigg, R. Scott, P. Stevenson, J. Chem. Soc. Perkin Trans. 1 1988, 1357-1364.

[3] For selected and recent references, see: a) L. Garcia, A. Pla-Quintana, A. Roglans, Org. Biol. Chem. 2009, 7, 5020-5027; b) L. Severa, L. Adriaenssens, J. Vávra, D. Šaman, I. Císařová, P. Fiedler, F. Teplý, Tetrahedron 2010, 66, 3537-3552; c) S.B. Suryawanshi, M.P. Dushing, R.G. Gonnade, C.V. Ramana, Tetrahedron 2010, 66, 6085-6096; d) T. Welsch, H.-A. Tran, B. Witulski, Org. Lett. 2010, 12, 5644-5647; e) N. Saito, T. Ichimaru, Y. Sato, Org. Lett. 2012, 14, 1914-1917; f) Y. Li, J. Zhu, L. Zhang, Y. Wu, Y. Gong, Chem. Eur. J. 2013, 19, 8294-8299; g) A.-F. Tran-Van, S. Götz, M. Neuburger, H.A. Wegner, Org. Lett. 2014, 16, 2410-2413.

[4] For selected references, see: a) K. Tanaka, K. Toyoda, A. Wada, K. Shirasaka, M. Hirano, Chem. Eur. J. 2005, 11, 1145-1156; b) T. Shibata, Y.-K. Tahara, J. Am. Chem. Soc. 2006, 128, 11766-11767; c) T. Shibata, Y.-K. Tahara, K. Tamura, K. Endo, J. Am. Chem. Soc. 2008, 130, 3451-3457; d) Y. Otake, R. Tanaka, K. Tanaka, Eur. J. Org. Chem. 2009, 2737-2747; e) Y. Komine, A. Kamisawa, K. Tanaka, Org. Lett. 2009, 11, 2361-2364; f) K. Tanaka, Y. Swada, Y. Aida, M. Thammathevo, R. Tanaka, H. Sagae, Y. Otake, Tetrahedron 2010, 66, 1563-1569; g) T. Shibata, M. Miyoshi, T. Uchiyama, K. Endo, N. Miura, K. Monde, Tetrahedron 2012, 68, 2679-2686; h) T. Shibata, M. Fujimoto, H. Hirashima, T. Chiba, K. Endo, Synthesis 2012, 3269-3284; i) K. Murayama, Y. Sawada, K. Noguchi, K. Tanaka, J. Org. Chem. 2013, 78, 6202-6210.

[5] For selected monographs and reviews, see: a) $\mathrm{N}$-Heterocyclic Carbenes in Transition Metal Catalysis, in: Topics in Organometallic Chemistry, (Ed.: F. Glorius), Springer, Heildelberg, 2007, vol. 21; b) NHeterocyclic Carbenes in Synthesis, (Ed.: S.P. Nolan), Wiley-VCH, Weinheim, 2006; c) S. Díez-González, N. Marion, S.P. Nolan, Chem. Rev. 2009, 109, 3612-3676; d) T. Dröge, F. Glorius, Angew. Chem., Int. Ed. 2010, 49, 6940-6952; e) R. Corberán, E. Mas-Marzá, E. Peris, Eur. J. Inorg. Chem. 2009, 1700-1716; f) N. Imlinger, K. Wurst, M.R. Buchmeiser, Monatsh. Chem. 2005, 136, 47-57; g) V. César, S. Bellemin-Laponnaz, L.H. Gade, Chem. Soc. Rev. 2004, 33, 619-636; h) T. Weskamp, V.P.W. Böhm, W.A. Herrmann, J. Organomet. Chem. 2000, 600, 12-22; i) W.A. Herrmann, C. Köcher, Angew. Chem. Int. Ed. Engl. 1997, 36, 2162-2187.

[6] I. González, A. Pla-Quintana, A. Roglans, Synlett 2009, 2844-2848

[7] Selected references of the use of $\mathrm{NHC}$ ligands for other metals in [2+2+2] cycloaddition reactions, see: a) N. Saino, D. Kogure, S. Okamoto, Org. Lett. 2005, 7, 3065-3067; b) A. Geny, S. Gaudrel, F. Slowinski, M. Amatore, G. Chouraqui, M. Malacria, C. Aubert, V. Gandon, Adv. Synth. Catal. 2009, 351, 271-275; c) R. M. Stolley, H. A. Duong, D. R. Thomas, J. Louie, J. Am. Chem. Soc. 2012, 134, 1515415162; d) S. Medina, G. Domínguez, J. Pérez-Castells, Org. Lett. 2012, 14, 4982-4985; e) S. K. Rodrigo, I. V. Powell, M. G. Coleman, J. A. Krause, H. Guan, Org. Biomol. Chem 2013, 11, 7653-7657.

[8] a) P. Diversi, G. Ingrosso, A. Lucherini, A. Minutillo, J. Mol. Catal. 1987, 40, 359-377; b) P. Perkins, K.P.C. Vollhardt, J. Am. Chem. Soc. 1979, 101, 3985-3987

[9] a) V. Conte, E. Elakkari, B. Floris, V. Mirruzzo, P. Tagliatesta, Chem. Commun. 2005, 1587-1588; b) I. González, S. Bouquillon, A. Roglans, J. Muzart, Tetrahedron Lett. 2007, 48, 6425-6428; c) Y.-Y. Lin, S.-C. Tsai, S.J. Yu, J. Org. Chem. 2008, 73, 4920-4928. 
[10] Y.-H. Wang, S.-H. Huang, T.-C. Lin, F.-Y. Tsai, Tetrahedron 2010, 66, 7136-7141.

[11] L. García, A. Roglans, R. Laurent, J.-P. Majoral, A. Pla-Quintana, A. M. Caminade, Chem. Commun. 2012, 48, 9248-9250.

[12] a) I. Thiel, A. Spannenberg, M. Hapke, Chem CatChem 2013, $2865-$ 2868; b) A. Geny, N. Agenet, L. Iannazzo, M. Malacria, C. Aubert, V. Gandon, Angew. Chem. Int. Ed. 2009, 48, 1810-1813.

[13] a) A. Corma, H. García, Adv. Synth. Catal. 2006, 348, 1391-1412; b) A. Zamboulis, N. Moitra, J. J. E. Moreau, X. Cattoën, M. Wong Chi Man, J. Mater. Chem. 2010, 20, 9322-9338; c) A. Monge-Marcet, R. Pleixats, X Cattoën, M. Wong Chi Man, Catal. Sci. Technol. 2011, 1, 1544-1563.

[14] C. J. Brinker, G. W. Scherrer, Sol-Gel Science: the Physics and Chemistry of Sol-Gel Processing, Academic Press, San Diego, 1990.

[15] K. J. Shea, J. J. E. Moreau, D. Loy, R. J. P. Corriu, B. Boury, in Functional Hybrid Materials, ed. P. Gómez-Romero and C. Sanchez, Wiley-VCH, Weinheim, 2004, pp. 50-8.

[16] a) Q. Yang, J. Liu, L. Zhang, C. Li, J. Mater. Chem. 2009, 19, 19451955; b) C. Sanchez, P. Belleville, M. Popall, L. Nicole, Chem. Soc. Rev. 2011, 40, 696-753; c) R. Ciriminna, A. Fidalgo, V. Pandarus, F. Béland, L. M. Ilharco, M. Pagliaro, Chem. Rev. 2013, 113, 6592-6620.

[17] a) F. Hoffmann, M. Cornelius, J. Morell, M. Fröba, Angew. Chem. Int. Ed. 2006, 45, 3216-3251; b) J. H. Clark, D. J. Macquarrie, S. J. Tavener, Dalton Trans 2006, 4297-4309; c) D. J. Macquarrie, Top. Catal. 2009, 52, 1640-1650; d) A. Mehdi, C. Reye, R. Corriu, Chem. Soc. Rev. 2011, 40, 563-574

[18] Y.-S. Fu, S.J. Yu, Angew. Chem. Int. Ed. 2001, 40, 437-440.

[19] S. Reinhard, P. Soba, F. Rominger, J. Blümel, Adv. Synth. Catal. 2003, 345, 589-602.

[20] I. Thiel, M. Hapke, J. Mol. Cat. A: Chem. 2014, 383-384, 153-158.

[21] For examples of $\mathrm{Rh}(\mathrm{I})-\mathrm{NHC}$ complexes functionalized with an alkyloxysilyl tail group, further immobilization on silica-based inorganic supports and their applications in catalytic hydrogenation and hydrosilylation, see: a) P. Li, W.A. Herrmann, F.E. Kühn,
ChemCatChem 2013, 5, 3324-3329; b) G. Lázaro, F.J. FernándezAlvarez, M. Iglesias, C. Horna, E. Vispe, R. Sancho, F.J. Lahoz, M. Iglesias, J.J. Pérez-Torrente, L.A. Oro, Catal. Sci. Technol., 2014, 4 62-70.

[22] A. Monge-Marcet, R. Pleixats, X. Cattoën, M. Wong Chi Man, J. Mol. Catal. A: Chemical 2012, 357, 59-66.

[23] G. Borja, A. Monge-Marcet, R. Pleixats, T. Parella, X. Cattoën, M. Wong Chi Man, Eur. J. Org. Chem. 2012, 3625-3635.

[24] S. Dastgir, K.S. Coleman, M.L.H. Green, Dalton Trans. 2011, 40, 661672.

[25] I. Peñafiel, I.M. Pastor, M. Yus, M.A. Esteruelas, M. Oliván, Organometallics 2012, 31, 6154-6161.

[26] K. Weigl, K. Köhler, S. Dechert, F. Meyer, Organometallics 2005, 24 4049-4056.

[27] K. S. W. Sing, D. H. Everett, R. A. W. Haul, L. Moscou, R. A. Pierotti, J. Rouquerol, T. Siemieniewska, Pure Appl. Chem. 1985, 57, 603-619.

[28] a) M. Larhed, C. Möberg, A. Hallberg, Acc. Chem. Res. 2002, 35, 717727; b) C. O. Kappe, Angew. Chem. Int. Ed. 2004, 43, 6250-6284; c) V. Polshettiwar, R. S. Varma, Acc. Chem. Res. 2008, 41, 629-639; d) B. K. Singh,N. Kaval, S. Tomar, E. Van der Eycken, V. S. Parma, Org. Process Res. Dev. 2008, 12, 468-474.

[29] a) R. Usón, L.A. Oro, J.A. Cabeza, Inorg. Synth. 1985, 23, pp 126; b) L.M. Green, D.W. Meek, Organometallics 1989, 8, 659-666.

[30] I. Ojima, A.T. Vu, J.V. McCullagh, A. Kinoshita, J. Am. Chem. Soc. 1999, 121, 3230-3231

[31] J. S. Lettow, Y. J. Han, P. Schmidt-Winkel, P. Yang, D. Zhao, G. D. Stucky, J. Y. Ying, Langmuir 2000, 16, 8291-8295.

[32] S. Brun, M. Parera, A. Pla-Quintana, A. Roglans, T. León, T. Achard, J. Solà, X. Verdaguer, A. Riera, Tetrahedron 2010, 66, 9032-9040.

[33] H. Kinoshita, H. Shinokubo, K. Oshima, J. Am. Chem. Soc. 2003, 125 7784-7785. 


\section{Entry for the Table of Contents}

\section{FULL PAPER}

Hybrid silica materials derived from rhodium(I) complexes bearing an $\mathrm{N}$ heterocyclic carbene ligand are obtained either by sol-gel or grafting processes. The materials are fully characterized by solid state NMR, $\mathrm{N}_{2}$ sorption measurements,

thermogravimetric analysis and elemental analysis. Their catalytic activity and recyclability are evaluated in the [2+2+2] cycloaddition of alkynes.

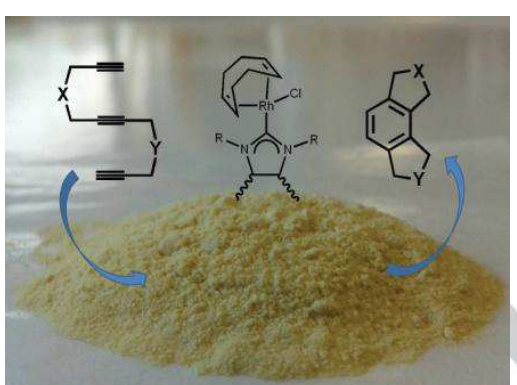

Martí Fernández, Meritxell Ferré, Anna Pla-Quintana, Teodor Parella, Roser Pleixats, ${ }^{*}$ Anna Roglans *

Page No. - Page No.

Rhodium-NHC Hybrid Silica Materials as Recyclable Catalysts for [2+2+2] Cycloaddition Reactions of Alkynes 